\title{
ANALISIS KOORDINASI KELEMBAGAAN DALAM PENYELENGGARAAN PENYULUHAN PERTANIAN \\ (Studi Kasus Kec. Berastagi Kab. Karo)
}

\author{
Oleh : \\ Nana Nurlina Ginting ${ }^{1)}$ \\ Matius Bangun 2) \\ UniversitasDarmaAgung, Medan ${ }^{1,2)}$ \\ E- mail: \\ nananurlianaginting@gmail.com ${ }^{\text {l) }}$ \\ $\underline{\text { mbresearch28@gmail.com }}^{2)}$
}

\begin{abstract}
The extension of the extension is strongly influenced by the extension institution itself both structurally from the center to the regions and functionally in the regions in relation to other cross-sectoral relations. The dynamics of changes in extension institutions from the central government have influenced institutional changes in the regions, both in terms of materials, methods and funding of extension. This research uses the descriptive qualitative method with the main problem is how to coordinate the implementation of agricultural extension in a Strutural and Functional manner and what efforts are made by the Karo Regency Government in responding to the dynamics of change so that it can still improve the performance of agricultural extension workers. The conclusion of this study is that in order to anticipate the dynamics of institutional changes, extension coordination is placed in the Functional (non-structural / non-structural / non-esslon) Agricultural Extension Coordination Secretariat which is accountable to the District Head through the Head of the Agricultural Service. Efforts that can be made by local governments in accordance with farmers' perceptions in terms of extension methods are: a. PPL visits to locations, $b$. Open Group Discussion, c. Demonstration Plots and d. Socialization.In terms of extension material are: a. Marketing Network, $b$. Latest drug, fertilizer and pesticide information, $c$. Nursery and Cultivation Techniques, and d. Post Harvest Handling; while striving for financing comes from: a. APBN, b. Provincial APBD, c. Karo Regency APBD and and d. Non-binding Third Party.
\end{abstract}

Keywords: Institutional Coordination, Agricultural Counseling

\begin{abstract}
ABSTRAK
Penyelengaraan penyuluhan sangat di pengaruhi oleh Kelembagaan penyuluhan itu sendiri baik secara Struktural dari Pusat ke Daerah maupun secara Fungsional di daerah dalam hubunganya dengan lintas sektoral lainnya. Dinamika perubahan terhadap kelembagaan penyuluhan dari pemerintah Pusat telah berpengaruh terhadap perubahan kelembagaan di daerah baik dari segi materi, metoda dan pembiayaan penyuluhan itu sendiri. Peneleltian ini menggunakan metode Kualitatif Diskriftif dengan permasalahan utama adalah bagaimana koordinasi penyelenggaraan penyuluhan pertanian secara Strutural dan Fungsional dan Apa upaya yang dilakukan Pemerintah Kabupaten Karo dalam menyikapi dinamika perubahan sehingga tetap dapat meningkatkan Kinerja para Penyuluh Pertanian. Kesimpulan dari Penelitian ini adalah dalam rangka mengantisispasi dinamika kerubahan kelembagaan penyuluhan maka koordinasi penyuluh di tempatkan dalam Sekretariat Koordinasi Penyuluhan Pertanian secara Fungsional (bukan struktural / Non esslon) yang bertanggung jawab kepada Bupati Kepala Daerah melalu Kepala Dinas Pertanian. Upaya yang dapat dilakukan Pemerintah Daerah sesuai dengan persepsi petani dari segi metode penyuluhan
\end{abstract}


adalah : a. Kunjungan PPL ke lokasi, b. Diskusi Group Terbuka, c. Demonstrasi Plot dan d. Sosialisasi ; dari segi materi penyuluhan adalah : a. Jaringan Pemasaran, b. Informasi Obat, pupuk dan pestisida terbaru, c. Tehnik Pembibitan dan Tehnik Budidaya, dan d. Penanganan Pasca Panen; sedangkan pembiayaan diupayakan berasal dari : a. APBN, b. APBD Propinsi, c. APBD Kabupaten Karo dan dan d. Pihak Ke-tiga yang tidak mengikat.

\section{Kata Kunci : Koordinasi, Penyelenggaraan, Penyuluhan,}

\section{PENDAHULUAN}

Tahun 1970-an saat program yang di kenal dengan revolusi hijau (green revolution) berkembang telah menunjukkan bukti yangampuh dengan pencapaian target swasembada beras nasional tahun 1984. Saat itu di sadari bahwa peran Penyuluhan pertanian banyak disebut sebagai salah satu kunci dari kisah sukses swasembada tersebut. Kini hampir seperempat abad setelah even tersebut, kini banyak permasalahan menyangkut penyuluhan sehingga penting untuk mengevaluasi kembali,

Namun dalam prakteknya terdapat perubahan kelembagaan baik struktural maupun fungsional dari pemerintahan ke pemerintahan sebagaimana tabel berikut.

Tabel 1. Perubahan Kelembagaan dan Sistem Penyuluhan

\begin{tabular}{|l|l|l|l|l|}
\hline No. & $\begin{array}{l}\text { Kurunn } \\
\text { waktu }\end{array}$ & $\begin{array}{l}\text { Kelembagaan } \\
\text { Penyuluhan }\end{array}$ & Sistem penyuluhan & Keterangan \\
\hline 1. & $\begin{array}{l}\text { Sampai } \\
\text { tahun 1984 }\end{array}$ & $\begin{array}{l}\text { Di bawah } \\
\text { koordinasi } \\
\text { Bimbingan Masal }\end{array}$ & dikendalikan dari Pusat & $\begin{array}{l}\text { Swasembada } \\
\text { Beras }\end{array}$ \\
\hline 2. & Sejak 1990 & $\begin{array}{l}\text { Berada pada } \\
\text { masing masing } \\
\text { sektor }\end{array}$ & $\begin{array}{l}\text { Sesuai kebijakan sektor } \\
\text { (Pertanian, Perikanan, } \\
\text { Kehutanan) }\end{array}$ & $\begin{array}{l}\text { merugikan } \\
\text { petani\&nelayan }\end{array}$ \\
\hline 3. & Sejak 2004 & $\begin{array}{l}\text { Di serahkan kepada } \\
\text { daerah }\end{array}$ & $\begin{array}{l}\text { Sistem Poli-Valen } \\
\text { bergabung semua sektor }\end{array}$ & $\begin{array}{l}\text { Penyuluh tidak } \\
\text { memahami } \\
\text { semua sektor }\end{array}$ \\
\hline 4. & Sejak 2018 & $\begin{array}{l}\text { Perikanan di tarik } \\
\text { ke Pusat, lainnya } \\
\text { masih di daerah }\end{array}$ & $\begin{array}{l}\text { Teknis di Pusat } \\
\text { Adminstrasi di daerah }\end{array}$ & $\begin{array}{l}\text { Di } \\
\text { pelaksanaan ke } \\
\text { daerah }\end{array}$ \\
\hline
\end{tabular}

Sumber : di olah dari berbagai sumber.

Kemudian sejak tahun 1990 kelembagaan penyuluhan di serahkan kepada kementerian masing namun di lapangan terjadi penolakan oleh petani nelayan karena mereka harus meluangkan waktu yang relatif lebih lama apabila mereka punya usaha yang bervariasi. Kemudian semenjak tahun 2004 seiring dengan pelaksanaan Otonomi daerah penyuluh diserahkan ke daerah sehingga penyelenggaraan tidak lagi terpadu. Selanjutnya untuk keterpaduan pada tahun
2018 yang lalu Kementerian Kelautan dan Perikanan kembali menarik para penyuluh Kelautan dan Perikanan kembali menjadi urusan pusat dan sampai penelitian ini di lakukan terdapat wacana kembali di kendalikan pemerintah pusat.Dinamika perubahan ini juga merubah kebijakan di daerah daerah tidak hanya kelembagaan Struktural juga hubungannya dengan lintas sektor lain secara fungsional.

Dinamika ini juga terjadi di Pemerintah Kabupaten Karo terjadi 
perubahan mulai dari sistem Bimas, Penyuluh berdasrkan sektor kemudian di rubah kembal Penyuluahn Sistem Polivalen di mana semua penyuluh sektor berada di bawah sat Unik Kerja yaitu Badan Koordinasi Penyluhan Pertanian.

\section{Rumusan Masalah}

Dai uraian latar Belakang tersebut di atas maka Rumusan Masalah dalam Penelitian ini adalah :

a. Bagaimanan Peneyelenggaraan Koordinasi Penyuluhan di Kabupaten Karo khususnya Kecamatan Berastagi berkaitan dengan kelembagaan baik Kelembagaan Struktural maupun Kelembagaan Fungsional.

b. Upaya upaya apa yang dilakukan untuk meningkatkan kinerja koordinasi penyelengaraan penyuluh pertanian di Kabupaten Karo khususnya Kecamatan Berastagi baik dari Metode, Materi maupun Pembiayaan Penyelenggaraan Penyuluhan.

Tujuan Penelitian

a. Untuk menginventarisasi permasalahan yang di hadapi Pemerintah Kabupaten Karo dalam Koordinasi Penyelenggaraan Penyuluhan Pertanian dari segi kelembagaan baik struktural maupun fungsional,

b. Langkah langkah yang di tempuh dalam Koordinasi Penyelengaraan Penyuluhan pertanian untuk meningkatkan kinerja Penyuluh Pertanian.

\section{TINJAUAN PUSTAKA}

\subsection{Koordinasi}

Dari kamus besar Menurut Bahasa Indonesia (2014) mendefinisikan koordinasi adalah kegiatan pengaturan suatu organisasi agar saling mendukung dan tidak saling bertentangan. Koordinasi tersebut memiliki tujuan untuk menciptakan serta menjaga supaya terjadi adanya suasana dan perilaku yang saling merespon dan mengantisipasi setiap unit kerja baik yang berhubungan atau tidak dalam suatu kegiatan. Hal ini agar kesuksesan masing-masing unit tidak mengganggu atau diganggu oleh unit lainya.

Handoko (2003:195) lebih lanjut menguraikan bahwa bahwa koordinasi tersebut merupakansuatu proses pengintegrasian tujuan-tujuan tertentu dan kegiatan-kegiatan pada satuan-satuan yang terpisah dari suatu organisasi untuk mencapai tujuan organisasi tersebut secara efisien. Dengan demikian koordinasi pada hakekatnya berupaya untuk menciptakan dan menjaga agar supaya suasana dan perilaku yang ada saling memberi respon dan mengantisipasi pada setiap unit kerja baik yang berhubungan mupun tidak. Hal ini agar kesuksesan masing-masing unit kerja tidak mengganggu atau diganggu oleh unit kerja yang lainya.

\subsection{Penyuluhan Pertanian}

Menyangkut tentang kelembagaan penyuluhan pertanian Presiden Joko Widodo berdasarkan PP Nomor 82 Tahun 2020 tentang pembentukan Komite Penanganan Virus Corona Tahun 2019 dan dan dalam rangka Pemulihan Ekonomi Nasional, telah membubarkan 18 lembaga dimana salah satu diantaranya adalah kelembagaan tentang penyuluhan yaitu Badan Koordinasi Nasional Penyuluhan Pertanian, Perikanan, dan Kehutanan yang dibentuk berdasarkan Peraturan Presiden No 10/2011 tentang Badan Koordinasi Nasional Penyuluhan Pertanian, Perikanan, dan Kehutanan. Berasarkan Perpres ini penyuluhan dilakukan secara polyvalen.

Dampak daroi PP resebut tentu sebagai konsekwensiny adanya pembubaran Badan Koordinasi Nasional Penyuluhan Pertanian, Perikanan, dan Kehutanan yang sebelumnya dibentuk berdasarkan PP No 10 Tahun 2011 tentang Badan Koordinasi 
Nasional Penyuluhan Pertanian, Perikanan, dan Kehutanan maka kini daerah daerah kembali menunggu petunjuk selanjutnya dari kementerian masing masing bagimana bentuk kelembagaan yang akan di bentuk di daerah daerah. Hal ini tentunya akan merubah kembali koordinasi yang harus dilakukan baik secara struktural maupun fungsional dalam menentukan Metode, Materi, dan Pembiayaan penyuluhan pertanian.

Namun pendekatan-pendekatan yang berbeda sering menjadi kendala karena ruang lingkup yang dibatasi dengan kelembagaan kelembagaan yang ada baik di pusat maupun di provinsi. Disinilah perlunya kebijakan di daerah bagaimana supaya kelembagaan itu fleksibel sehingga faktor faktor dinamika dalam kelembagaan tidak menjadi penghamba dalam peningkatan kinerja penyuluh,

Kementerian Pertanian RI Jakarta (2010) menyatakan Penyuluhan pertanian didefinisikan sebagai suatu sistem pendidikan non formal untuk petani dan keluarganya, yang tujuan meningkatkan kemampuan dan pengetahuan, kemampuan dan mengembangkan sikap positif terhadap perubahan yang akan menambah kepercayaan diri di dalam pengusahaan usahataninya dalam memecahkan permasalahan yang dihadapi dengan mengadopsi / menerapkan teknologi yang lebih baik di dalam usahatninya sebagai aktivitas utamanya.

\subsection{Dinamika Kelembagaan Penyuluhan}

Dasar Hukum dari penyelenggaran penyuluhan memiliki dinamia yang sangat tinggi. Akibat seringnya terjadi perubahan tersebut menyebabkan perubahan prioritas kebijkan di pemerintah pusat yang berimplikasi terhadap kelembagaan penyuluhan di daerah yang pada akhirnya mempengaruhi kinerja penyuluh itu sendiri.

Perubahan yang sering terjadi tersebut yang dimulai dari pelaksanaan otonomi daerah dengan berlakunya Undang Undang No. 32 tahun 2004 yang terakhir di rubah dengan Undang Undang Nomor 23 Tahun 2014 bahwa dari berbagai pemerhati dan peneliti bidang pertanian khususnya penyelengaraan berkesimpulan bahwa telah terjadi penurunan kinerja penyuluhan karena penyelenggaraannya ditempatkan pada posisi minor (kurang menjadi perhatian pemerintah daerah).

\subsection{Penyelenggaraan Penyuluhan}

Sampai saat ini penelitian ini di lakukan bahwa penyelenggaraan penyuluhan yang di gunakan termasuk di Kabupaten Karo masinh mengacu pada Peraturan Menteri Pertanian Nomor 03 / Permentan / SM.200/1/2018 tentang rumusan Pedoman dan Penyelenggaraan Penyuluhan Pertanian yang menyangkuKebijakan, strategi, dan program;serta Kelembagaan; Ketenagaan;serta Pelaksanaan;Prasarana dan sarana;Mekanisme dan tata hubungan kerjPembinaan dan pengawasan;Pemantauan, evaluasi, dan pelaporan; danPembiayaan.

Adapun di Kabupaten / Kota Dinas yang menyelenggarakan fungsi Penyuluhan Pertanian di daerah berfungsi sebagai penyelenggara Penyuluhan Pertanian. Jika potensi komoditas pertaniannya dominan ditetapkan sebagai pengelola satuan administrasi pangkal (satminkal) Penyuluh Pertanian.

\subsection{Materi Penyuluhan}

Materi Penyuluhan Pertanian disusun berdasarkan kebutuhan dan kepentingan Pelaku Utama dan Pelaku Usaha dengan memperhatikan kemanfaatan, kelestarian sumber daya pertanian, dan pengembangan kawasan Pertanian. Materi Penyuluhan Pertanian memuat unsur : a. pengembangan sumber daya manusia; $b$. peningkatan ilmu pengetahuan, teknologi, informasi, ekonomi, manajemen, hukum, dan kelestarian lingkungan; dan c. penguatan Kelembagaan Petani.

Materi Penyuluhan Pertanian diarahkan untuk mengembangkan 
kapasitas Pelaku Utama dan Pelaku Usaha dalam mengelola usaha tani yang menguntungkan dan ramah lingkungan untuk meningkatkan pendapatan dan kesejahteraan. Materi Penyuluhan Pertanian yang memuat teknologi dapat mencakup inovasi teknologi yang bersumber dari pengetahuan tradisional. Pengembangan kapasitas Pelaku Utama untuk meningkatkan profesionalisme dan daya saing Pelaku Utama dalam globalisasi perdagangan regional dan internasional. Dapat dilaksanakan melalui pendidikan dan pelatihan serta sertifikasi kompetensi sesuai dengan ketentuan peraturan perundang-undangan.

\subsection{Penelitian Terdahulu}

Margono Slamet (2001), menyatakan bahwa pentingnya kebijakan desentralisasi penyuluhan pertanian adalah untuk menggantikan sistem penyuluhan yang bersifat regulatif sentralistis ke arah sistem penyuluhan yang fasilitatif partisipatif. Kemudian dari sefi strategi penyuluhan Sumardjo, 1999 mengatakan bahwa strategi penyuluhan yang digunakan selama ini lebih bersifat interpersonal. Berdasarkan fakta-fakta penelitian dan hasil analisis serta hasil pengamatan di lapangan yang menunjukkan kinerja penyuluh pertanian tergolong rendah, maka diperlukan perhatian lebih serius dari pemerintah daerah (BP4K), untuk memperbaiki kinerja penyuluh pertanian di Kota Tidore Kepulauan.

Isran Noor (2012) tentang kinerja penyuluhan adalah Faktor-faktor yang mempengaruhi kinerja penyuluh pertanian yaitu: a) Faktor Internal; terdiri dari: pendidikan formal, pelatihan, umur, motivasi, pemanfaatan media penyuluhan, dan masa kerja/ pengalaman kerja penyuluh pertanian. b) Faktor Eksternal; terdiri dari: ketersediaan sarana dan prasarana yang diperlukan, sistem penghargaan, jarak wilayah kerja, jumlah desa binaan, jumlah kelompok tani binaan, teknologi informasi, tingkat partisipasi aktif petani, hubungan dalam organisasi, dan dukungan pembinaan dan supervisi.

\subsection{Keraangka Pemikiran}

Dari Tinjauan Teoritis baik berupa Litratur maupun hsilhasil Kajian maka Kerangka Pikiran dalam penelitian ini adalah sebagai berikit :

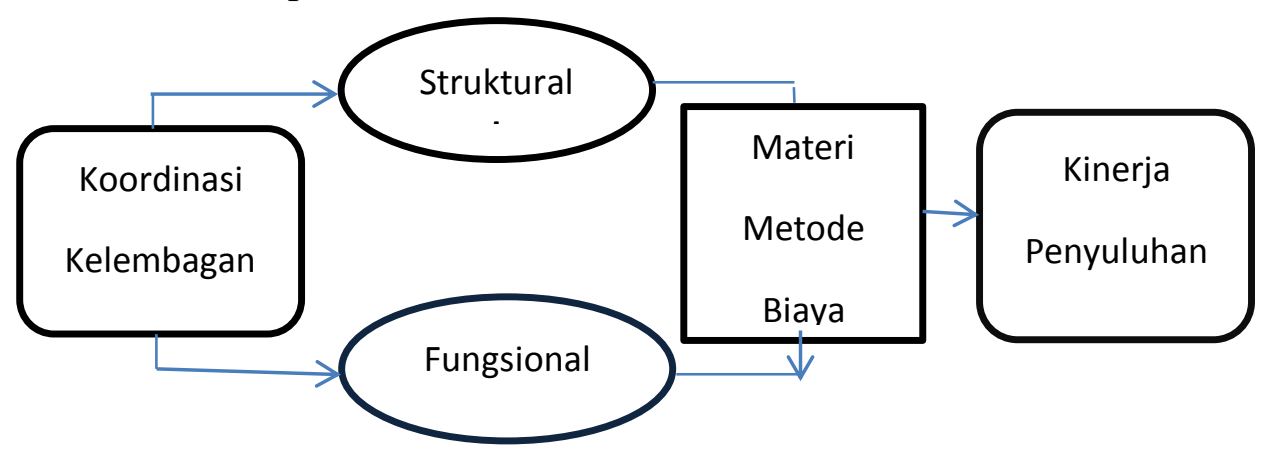

Gambar 1. Kerangka Pikiran didisain oleh Peneliti, 2020

\section{METODE PELAKSANAAN}

3.1 Jenis dan Sumber Data

a. Data Primer di kumpulkan dari tangan yang pertaama melalui Wawancara baik dengan informan Kunci maupun Informan Tambahan. Informan utama yaitu Kepala Dinas / Staf, Kepala Bappeda atau bidang / staf serta Kepala Balai Penyuluh Pertanian
(BPP) atau staf yang menangani yang berhubungan dengan teksis penyelenggaraan penyuluhan. Disamping informan Utama / Kunci juga Informan Tambahan yaitu camat, kepala desa, kelompok tani, penyedia jasa sarana pertanian, lemabga Keuangan tani serta pihak pihak yang relevan dengan penelitian ini. Pertanyaan 
yang di ajukan adalah berkaitan dengan materi penyulahan serta metode penyuluhan yang mereka kehendaki.

b. Data Primer juga di kumpulkan melalui observasi yng berhubungan dengan penyelenggaraan penyuluhan terhadap aktivitas penyuluh, kelompok tani binaan, alat peraga yang digunakan dan sejenisnya yang dilakukan di Kantor BPP Kuta Gadung Berastagi, di kelompok Tani dan juga beberapa petani yang mewakili.

c. Disamping data Primer juga di lakukan pengumpulan Data Sekunder dari Studi literatur jurnal dan sejenisnya serta kumpulan peraturan peraturan baik dalam bentuk Undang-Undang, Peraturan pemerintah dan turunannya. Kemudian dari dokumentasi berupa gambar dan sejenisnya yang di dapatkan dari penyelenggaraan penyuluhan Pertanian baik di Kantor Dinas Pertanian dan BPP Kuta Gadung Berastagi.

\subsection{Pendekatan Penelitian}

Penelitian di bedakan atas kuantitatif dan Kualitatif. Penelitian kualitatif Menurut Moleong (2005:6), adalah merupakan penelitian yang bermaksud untuk memahami suatu fenomena tentang apa yang dialami oleh subjek penelitian misalnya yang menyangkut perilaku, persepsi, motivasi, tindakan, dan sejenisnya secara holistic dalam bentuk uraian secara kata kata dengan tetap menggunakan metode alamiah. Metode pendekatan kualitatif jauh sifat dan jenis penelitian ini bersifat terbuka, dan berakhir dengan dilakukannya wawancara dalam jumlah relatif kelompok kecil yang diwawancarai secara mendalam dengan analisis bersifat deskriptif.

\subsection{Metode Penelitian}

Metode penelitian deskriptif Menurut Whitne (1960), merupakan suatu metode pencarian fakta untuk menggunakan interprestasi yang tepat. Dalam penelitian ini mempelajari tentang masalah-masalah yang ada didalam masyarakat dan juga tata cara yang digunakan dalam masyarakat serta dalam situasi-situasi tertentu. Penelitian deskriptif merupakan jenis metode yang menggambarkan suatu objek dan subjek yang sedang diteliti tanpa adanya rekayasa. Termasuk mengenai hubungan antara kegiatan, pandangan, sikap dan proses-proses yang memiliki pengaruh dalam terhadap suatu fenomena yang terjadi.

\subsection{Analisa Data}

a. Analisis Delphiyaitu suatu analisis yangmenurut Irfan Adyatama (2018), menyatakan bahwa metode penilaian tentang hal yang kompleks ketika informasi yang tepat tidak tersedia. Dalam penelitian ini analisis dilakukan untuk mengumpulkan informasi dari para informan Utama maupun Informan Tambahanuntuk mendapatkan suatu kesepahaman tentang suatu hal.

b. Analisis Kebijakan menurut Panjar Simatupang (2013) menyatakan Analisis kebijakan iadalah suatu proses atau kegiatan menganalisis informasi termasuk hasil-hasil penelitian, untuk menghasilkan rekomendasi atau opsi desain suatu kebijakan publik.

\section{HASIL DAN PEMBAHASAN}

4.1.Dinamikan Kelemebagaan Penyuluh Berbagai pemerhati dan peneliti bidang pertanian khususnya penyelengaraan berkesimpulan bahwa telah terjadi penurunan kinerja penyuluhan karena penyelenggaraannya ditempatkan pada posisi minor (kurang menjadi perhatian pemerintah daerah). Kurangnya perhatian pemerintah tersebut dapat di maklumi mengingat peraturan yang berubah serta pemahaman akan pentingnya penyuluh pertanian yang kurang memadai tentang penyuluhan itu sendiri. 
Disamping perubahan perubahan kelembagaan penyelenggaraan penyuluhan sesuai dengan dinamik perubahan yang ada pada tatanan kehidupan nasional terdapat juga berbagai regulasi lain yang ikut mempengaruhi kelembagaan penyuluhan pertanian yang dimulai dengan : a) UU No. 19 Tahun 2013 tentang Perlindungan dan Pemberdayaan Petani No. 131, b) Peraturan Menteri Pertanian Nomor 47/PERMENTAN/ SM.010/9/2016 tentang Pedoman Penyusunan Programa Penyuluhan Pertanian No, 1477);c) Permentan No. 67/PERMENTAN /SM.010/9 tahun 2016 tentang Pedoman Penyusunan Programa Penyuluhan Pertanian.

\subsection{Penyelengaraan Penyuluhan}

Diakui oleh kepala Balai Penyuluh Pertanian (BPP) Kuta Gadung sebagai Informan Kunci bahwa Dinamika Perubahan yang terjadi pada aspek kelembagaan menyebabkan sulitnya koordinasi baik secara strutuktural maupun secara fungsional yang berimbas ke daerah daerah dalam penyelenggarann penyuluhan. Hal yang sama disampaikan oleh Informan penunjang yaitu penyuluh di kantor balai Penyulu Kecamatan (BPP) Kuta gadung menyatakan bahwa sering terjadi suatu peraturan baru di implementasikan dalam penyelenggaraan penyuluhan Kabupaten Karo dan belum dievaluasi namun sudah menyusul lagi ada peraturan baru yang mengharuskan ada penyesuaian dalam penyelenggaran penyuluhan baik dari aspek Metode, Materi maupun pembiayaan.

Pada saat penelitian ini di lakukan kondisi di Kabupaten Karo berdasarkan ketrangan para Informan (Kadis Pertanian, Camat Berastagi, penyuluh Pertanian Kecamatan Berastagi) menunjukkan gejala yang sama, di mana akhir akhir ini keberadaan para penyuluh secara oragnisasi terjadi stagnasi di mana para penyuluh mengalami dinamika perubahan kelembagaan sesuai dengan kebijakan yang di ambil Pemerintah Pusat.

4.3. Koordinasi Kelembagaan
Keragaan Kelembagaan Penyuluhan Pertanian di Kabupaten Karo berada di bawah Badan Pelaksana Penyuluh Pertaniaian namun berdasarkan hasil observasi, kelembagaan penyuluhan pertanian di Kabupaten Karo ini seperti masa transisi karena adanya perubahan perubahan kebijakan secara Nasional di mana kondisi saat ini penyuluh perikanan dan Kehutanan sudah berada di bawah organik Kementerian sedangkan penyuluh pertanian baik tanaman pangan, hortikultura, peternakan dan perkebunan di wacanakan kembali ke Kemnterian Pertanian. Namun saat penelitian ini dilakukan proses penyuluhan masih berjalan mempedomani kelembagaan yang ada sebelumnya. Berubah ubahnya sistem kelembagaan dari penyelenggaraan penyuluhan ini sangat berpengaruh terhadap materi, metode serta pembiayaan penyelenggaraan penyuluhan itu senfiri.

a. Kelembagaan Struktural.Dalam penelitian ini yang dimaksud dengan kelembagaan struktural adalah yang memiliki garis komando dari kabupaten sampai ke lapangan. Sesuai dengan Keputusan Bupati Karo Nomor 34 Tahun 2015 tentang Komisi Penyuluhan Pertanian, Perikanan dan Kehutanan Kabupaten Karo Bupati Karo dalam menetapkan kebijakan dan strategi penyuluhan, sesuai ketentuan Pasal 14 ayat (1) Undang-Undang Nomor 16 Tahun 2006 tentang Sistem Penyuluhan Pertanian, Perikanan dan Kehutanan, Bupati dibantu Komisi Penyuluhan Tingkat Kabupaten; Namun dalam kenyataan Komisi tersebut sampai penelitian ini di bentuk belum terbentuk. Informan Dinas Pertanian Kabupaten Karo juga berpendapat bahwa sering terjadinya perubahan kelembagaan menyebabkan keengganan pemerintah daerah untuk segera menetapkan Komisis Penyuluhan di Kabupaten Karo. Hal ini menjadi salah satu penyebab rendahnya kinerja penyuluh di Kabupaten Karo. 
b. Kelembagaan Fungsional. Demikian juga Kelembagaan Fungsional adalah koordinasi penyelenggaraan penyuluhan yang melibatkan instansi terkait. Dalam hal ini seuai dengan informan Dinas Pertanian Kabupaten Karo bahwa lembaga lembaga yang terkait dalam penyelengaraan penyuluhan Pertanian adalah Balai Penyuluhan Pertanian, Camat, Kepala Desa, Kelompok Tani serta pelaku usaha bidang pertanian.

\subsection{Metode Penyuluhan}

Sebenarnya sejak tahun 1980-an pemerintah RI melalui Kementerian Pertanian telah memperkenalkan dan mencoba mengembangkan pendekatan penyuluhan partisipatif melalui kegiatan proyek proyek pertanian. Pendekatan partisipatif dimana petensi yang berperan Tabel 2. Metode Penyuluhan di Kecamatan Berastagi Kabupaten Karo.

\begin{tabular}{|l|l|c|l|}
\hline $\begin{array}{c}\text { Urutan } \\
\text { Metode }\end{array}$ & \multicolumn{1}{|c|}{ Metode } & Jumlah & \multicolumn{1}{|c|}{ Persentase } \\
\hline 1. & Kunjungan PPL & 15 & 50.00 (Pertama) \\
\hline 2. & $\begin{array}{l}\text { Diskusi Group } \\
\text { Kecil }\end{array}$ & 8 & 27,67 (Kedua) \\
\hline 3 & Demonstrasi Plot & 5 & 16.67 (Ketiga) \\
\hline 4. & Sosialisasi & 2 & 06.67 (Keempat) \\
\hline
\end{tabular}

Hasil wawancara dengan informan tambahan, 2020

\subsection{Materi Penyuluhan}

Berdasarkan analisis Materi Penyuluhan Pertanian perlu disusun berdasarkan kebutuhan dan kepentingan petani yang menggunakan teknologi dengan memperhatikan aspek aspek teknis kemanfaatan, dan kelestarian sumber daya aktif berdasrkan informan penyuluh yang ada di Kecamatan Berastagi belum dapat terlaksana dengan baik dimana jika terdapat permasalahan dalam usaha taninya belum memanfaatkan Balai Penyuluh Pertanian (BPP) sebagai wadah pemecahan masalah. Kondisi ini juga tak terlepas dari kesiapan BPP dan penyuluhnya baik sarana dan prasarana, sumberdaya manusi penyuluhnya yang mungkin juga menjadi penyebabnya.

Dari rangkuman informan tambahan baik penyuluh, kepala desa dan keinginan para pengurus kelompok dan petani itu sendi menunjukkan keinginan prioritas metode penyuluhan yang di inginkan adalah Kunjungan PPL ke lokasi, Diskusi Group Terbuka, Demonstrasi Plot, serta Sistem Sosialisasi

Tabel 3. Keinginan petani terhadap materi penyuluhan, 2020

\begin{tabular}{|l|l|c|c|}
\hline No. & \multicolumn{1}{|c|}{ Materi } & Jumlah & Persentase \\
\hline 1. & Jaringan Pemasaran & 9 & 30,00 \\
\hline 2, & Informasi teknologi baru & 8 & 26,67 \\
\hline 3. & Tehnik Pembibitan & 6 & 20,00 \\
\hline 4. & Tehnik Budidaya & 5 & 16.67 \\
\hline 5. & Penanganan pasca panen & 2 & 06,67 \\
\hline
\end{tabular}

Sumber : Diolah dari Hasil Wawancara lapangan

\subsection{Pembiayaan Penyuluhan}

Dari informan Dinas Pertanian Kabupaten Karo dan juga Penyuluh sebagai informan tambahan serta obervasi lapangan terdapat dana yang langsung di kelola oleh PPL yaitu dana oprasional dari APBD Kabupaten Karo. sementara ada pertanian. Adapun keinginan petani / kelomok tani terhadap materi penyuluhan sebagaiman di gambarkan pada tabel berikut :

Adapun urutan prioritas Materi Penyuluhan yang diminati adalah sebagai berikut : dana penunjang yang langsung dalam kegiatan baik dari APBN maupun APBD, dana pihak ke tiga dari pelaku usaha yaitu pelaku usaha bibit, pupuk, pestisida dan obat obatan serta dana bantuan Sosial yang di terima oleh kelompok maupun perorangan khusus di masa pendemi Covid 
19. Adapun uraina tentang sumber

di uraikan berikut ini :

sumber pembiayaan tersebut sebagaimana

Tabel 11. Pembiayaan Penyuluhan Kec. Berastagi, 2020

\begin{tabular}{|l|l|l|}
\hline No. & \multicolumn{1}{|c|}{ Sumber Dana } & \multicolumn{1}{c|}{ Jenis Kegiatan } \\
\hline 1. & APBN & Penyusuna Program \\
\hline 2. & APBD Propinsi & Penyusunan Program,Demonstrasi Plot \\
\hline 3. & APBD Kab, Karo & Oprasional Penyuluhan,Demonstrasi Plot \\
\hline 4. & Dana Pihak Ke-tiga & Partisipasi Pihak ke 3 \\
\hline 5. & $\begin{array}{l}\text { Penunjang tdk } \\
\text { Langsung }\end{array}$ & Bansos yang di terima Kelompok \\
\hline
\end{tabular}

Sumber : diolah dari hasil observasi lapangan, 2020APBN.

Dipusat dana atau pembiayaan

penyelenggaraan penyuluhan berada di

satuan Kerja (Satker) Badan PPSDMP

yang bertugas sesuai dengan ketentuan

peraturan perundang-undangan sebagai

lembaga yang berada di bawah

Kementerian Pertanian dan Kepala Badan

adalah pejabat yang di angkat dan

bertanggung jawab kepada Menteri

Pertanian.

a. APBD Propinsi.Pembiayaan di

Propinsi adalah usulan usulan yang di lakukan oleh Kabupaten / Kota Sumatera Utra yang sumber danaya dapat dari APBN maupun APBD Propinsi. Penyelenggaraan penyuluhan di Kecamatan Berastagi di harapkan sudah sesuai dengan RPJM Kabupaten Karo dan Propinsi Sumatera Utara yang berorintasi dari kebijakan penyelenggaraan pemerintahan pusat. Kebijakan kedepan penyelenggaran penyuluhan terjadi sinkronisasi dari pusat sampai ke daerah berorientasi pada sistem dan usaha agribisnis yang berdaya saing, berkerakyatan, berkelanjutan.

b. APBD Kabupaten Karo. Kabupaten. Di Karo Kabupaten dinas yang membidangi penyuluhan adalah dinas pertanian atau ada juga yang berada di bawah badan atau kantor penyuluhan pertanian. Ketenagaan Penyuluhan Pertanian. Dana untuk penyelenggaraan penyuluhan terbagi atas dua yaitu dan untuk kegiatan penyuluhan serta dana oprasional penyuluh itu sendir. Dana untuk kegiatan penyuluhan umumnya untuk pembuatan alat peraga berupa brosur serta demonstrasi plot yang langsung di lakukan di lahan masyarakat sebagai sebuah percontohan. Sementara itu dana oprasional untuk penyuluh berupa dana untuk transportasi dan peralatan alat tulis kantor.

c. Dana Pihak Ke Tiga. Dana dari pihak ketiga adalah dana dana yang tidak mengikat yang dapat di gunakan untuk kegiatan penyuluhan pertanian. Hal ini biasanya dilakukan penyuluh bekerjasama dengan pelaku usaha pembibitan, penyalur pupuk serta obat obatan. Dalam hal ini tentu ada kerjasama yang saling menguntungkan di mana para petani mendapatkan pengetahuan dan ketrampilan tentang pengelolaan usahanya dan dari pihak pelaku usaha juga kesempatan untuk memperkenalkan produknya. Kegiatan yang di lakukan di Kecamatan Berastagi antara lain adalah cara penggunaan pestisida dan tehnik pemupukan tanaman.

Penunjang Tidak Langsung. Penunjang tidak langsung ini adalah adanya kegiatan di luar pertanian api juga dapat di manfaatkan untuk kegiatan penyuluhan. Pada saat penelitian ini di lakukan ada juga sosialisasi di beberapad desa di Kecamatan Berastagi berupa petugas dar kecamatan tentang kebijakan pemerintah menangani masalah keterpurukan di masa Covid 19.

\section{SIMPULAN}

5.1Simpulan 
a. Koordinasi Kelembagaan baik Strutural maupun Fungsional mendapat hambatan karena dinamika perubahan kebijakan Penyelenggaraan Penyuluhan oleh Pemerintah Pusat,

b. Secara Fungsional belum di bentuknya Forum Koordinasi Penyelenggaraan Penyuluhan di Tingkat Kabupaten maupun Kecamatan sebagaimana di amanahkan Undang Undang.

c. Kelembagaan yang di inginkan dalam penyelenggraan penyuluhan di kabupaten karo adalah Sekretaiat Penyuluh Pertanian yang bertanggung jawab Kepada Kepala Dinas Pertanian melalui Seketaris Dinas.

d. Urutan Metode Penyuluhan yang diinginkan adalah berdasarkan Kunjungan PPL ke lokasi Diskusi Group Terbuka Demonstrasi Plot dan Sosialisasi. Adapun urutan prioritas Materi Penyuluhan yang diminati adalah sebagai berikut : Jaringan Pemasaran, Informasi Obat, pupuk dan pestisida terbaru, Tehnik Pembibitan, Tehnik Budidaya, Penanganan Pasca Panen.

e. Sumber Sumber Pembiayan dari Penyelenggaran Penyuluhan di Kecamatann Berastagi adalah : APBN (Penyusuna Program), APBD Propinsi (Penyusunan Program, Demonstrasi Plot) APBD Kab, Karo (Oprasional Penyuluhan, Demonstrasi Plot), Dana Pihak Ke-tiga (Partisipasi Pihak ke 3) Penunjang tdk Langsung (Bansos yang di terima Kelompok).

\subsection{Rekomendasi}

a. Bupati Karo agar segera membuat dan memfungsikan Forum Koordinasi Penyelenggaran Penyuluhan tingkat kabupaten, dan Camat Berastagi membuat dan memfungsikan Forum Koordinasi Penyelenggaraan penyuluhan Tingkat Kecamatan.

b. Pemerintah Kab Karo dan jajarannya agar secara aktif mendapatkan informasi tentang jaringan pemasaran, penemuan produk baru (pupuk, pupuk dan obat), teknik budidaya dan penenganan pasca panen dari Balai Pengkajian Teknologi Pertanian (BPPTP) Sumatera Utara dan badan badan Penelitian dan Pengembangan Kementerian yang ada di Pemerintah Pusat.

c. Sehubungan dengan hasil temuan dalam penelitian ini bahwa metode penyuluhan yang paling di minati adalah kunjungan lapangan oleh PPL maka pemerintah daerah melengkapi para PPL tersebut dengan peralatan kerja seperti laptop, alat transportasi minimal kenderaan roda dua, serta perlindungan asuransi dalam pelaksanaan tugas.

d. Pemerintah Kabupaten Karo untuk meningkatkan Kinerja Penyuluh dapat mefasilitasi kerjasama pembiayaan dengan Pihak Ketiga seperti pelaku usaha sarana dan prasarana pertanian, tokoh masyarakat desa yang ada di luar desa, dosani dari perhimpunan komunitas baik agama maupun adat serta dan hibah lainnya.

\section{DAFTAR PUSTAKA}

\section{Buku-Buku :}

Basuki Irianto dkk. 2001. Evaluasi Adopsi dan Dampak Penelitian dan Pengkajian IPPTP. Laporan Penelitian, Instalasi dan Pengkajian Teknologi Pertanian. Mataram. Gama, Judistira K. 1996. Ilmu-ilmu sosial . Dasar-Konsep-Proposisi. Program Pascasarjana. Universitas Padjadjaran, Bandung.

Hanafi

Abdillah, 1987. Memasyarakatkan Ide-ide Baru ; Disarikan dari Karya Everet Roger dan F. Floyd Shoemaker "Communication of Innovations". Penerbit Usaha Nasional. Surabaya.

Irfan Adyatama (2013) Direktorat jenderal Keuangan dan BUMN Badan Perencanaan pembangunan nasional. Analisi Kebijakan Pertanian Volume I, Edisi maret. 
Nagel, Uwe Jens 1997. Alternative approaches to organizing extension dalam " Improving Agricultural Extension. A Reference Manual “. Food and Agriculture Organization of the United Nations. Rome.

Panjar Simatupang (2013) Analisis Kebijakan, Konsep dasar dan Prosedur Pelaksanaan. Analisis kebijakan Pertanian Jakarta. Puspadi, Ketut, 2002. Rekonstruksi Sistem Penyuluhan Pertanian (Disertasi) Bogor. Program Pascasarjana Institut Pertania. Bogor. Valera, Jaime, B., Vicente A, Marinez, dan Ramino F. Plopino, 1987. An Intro duction Extension Delivery Systems. Island Publishing House, Inc., Manila. Philippines.)

\section{Peraturan Peraturan :}

PP Nomor 43 Tahun 2009 tentang Pembiayaan, Pembinaan, Pengawasan Penyuluhan Pertanian, Perikanan dan Kehutanan (Lembaran Negara Republik Indonesia Tahun 2009 N0. 87 Tambahan Lembaran Negara RepublikIndonesia Nomor 5018);
PP No 18 / 2016 tentang Perangkat Daerah (Lembaran Negara Republik Indonesia Tahun 2016 Nomor 114, Tambahan Lembaran Negara Republik Indonesia Nomor 5887);

Peraturan Menteri Pertanian Nomor 03/PERMENTAN/ OT.140/1/2011 tentang Pedoman Pembinaan Tenaga Harian Lepas Tenaga Bantu Penyuluh Pertanian (Berita Negara Republik Indonesia Tahun 2011 Nomor 51);

Undang-Undang Nomor 19 Tahun 2013 tentang Perlindungan dan Pemberdayaan Petani (Lembaran Negara Republik Indonesia Tahun 2013 Nomor 131, Tambahan Lembaran Negara Republik Indonesia Nomor 5433);

Undang-Undang Nomor 23 Tahun 2014 tentang Pemerintahan Daerah (Lembaran Negara Republik Indonesia Tahun 2014 Nomor 244, sebagaimana telah beberapa kali diubah, terakhir dengan Undang- Undang Nomor 9 Tahun 2015 tentang Perubahan Kedua atas Undang-Undang Nomor 23 Tahun 2014 tentang Pemerintahan Daerah. 